\title{
MELANSIA: PEMBERDAYAAN LANSIA ANTI-STRES DI PANTI WERDHA DENGAN METODE BERKEBUN TANAMAN HERBAL
}

\author{
Taesar Hawaij', Devi Fitri Rahayu², Fahmi Kurniahadi3, Nadiyah Salsabilah4, \\ Anna Vipta Resti Mauludyanis \\ 1,2,3,4,5,Institut Pertanian Bogor \\ ${ }^{1}$ E-mail address taesar 28@apps.ipb.ac.id; ${ }^{2}$ E-mail address fitridevi48@gmail.com; \\ 3 E-mail address fahmi kurniahadi@apps.ipb.ac.id; 4 E-mail address \\ nadiyahsalsabilah@gmail.com; 5 E-mail address anna-vipta@apps.ipb.ac.id
}

\begin{abstract}
Health care for elderly must be aimed for maintaining a productive and healty life. Unfortunately, most of the activities carried out by the nursing home are restricted, it's causing the elderly being less activities. Planting is one of the activites that can be overcome the issue. Planting activities can be used as an intervention technique and connection to nature that is used as a therapy and rehabilitation program. The aimed of this program is to empower the elderly for stay healthy and productive through the planting of herbal plants. This program was carried out at the Tresna Werdha Social Home, Budi Mulia 3, South Jakarta which was held from June to September 2021 by blended (offline : online $=60: 40$ ). This program includes 10 series of activities that is consist of planting herbal plants, education, and nutrition consultation. This program was followed by 16 participant which is 13 female and 3 male elderly and including nursing home staff. Based on the results of the activity, there was a significant increase in the proportion of the elderly with a high level of spiritual wellbeing up to $88 \%$. It can be concluded that Melansia is a solution in antistress training for elderly during the pandemic through farming herbal plant activities that are proven to reduce stress levels in the elderly, and can increase the level of spiritual well-being and physical activity of the elderly.
\end{abstract}

Keywords: Depression, Garden, Herbal Plant

\begin{abstract}
Abstrak
Upaya pemeliharaan kesehatan bagi lansia harus ditujukan untuk menjaga agar tetap hidup sehat dan produktif. Berdasarkan hal tersebut, sangat disayangkan bahwa kegiatan dan aktivitas yang dilakukan oleh pihak Panti werdha sebagian besar masih terbatas. Salah satu kegiatan yang dapat dilakukan untuk mengatasi hal tersebut adalah dengan kegiatan bercocok tanam. Kegiatan bercocok tanam dapat dijadikan sebagai suatu teknik intervensi dan kedekatan terhadap alam yang digunakan sebagai program terapi dan rehabilitasi. Tujuan dari kegiatan ini untuk memberdayakan lansia agar tetap sehat dan produktif melalui penanaman tanaman herbal. Kegiatan ini dilaksanakan di Panti Sosial Tresnda Werdha (PSTW) budi
\end{abstract}


mulia 3, Jakarta Selatan. Kegiatan ini dilaksanakan pada bulan Juni hingga September 2021 secara blended (daring : luring $=60: 40$ ). Kegiatan ini terdiri dari 10 rangkaian kegiatan, baik dari kegiatan berkebun hingga edukasi dan konsultasi gizi. Kegiatan Melansia diikuti oleh 16 peserta yang terdiri dari 13 perempuan dan 3 laki-laki dengan kisaran umur 55-89 tahun yang juga melibatkan karyawan Panti. Berdasarkan hasil kegiatan, Terdapat peningkatan yang signifikan pada proporsi lansia dengan tingkat kesejahteraan spiritual yang tinggi hingga mencapai 88\%. Dapat disimpulkan bahwa Melansia merupakan solusi dalam melatih lansia antistres di masa pandemi melalui kegiatan berkebun tanaman herbal yang terbukti dapat menurunkan tingkat stres pada lansia, serta dapat meningkatkan tingkat kesejahteraan spiritual dan aktivitas fisik lansia.

Kata Kunci: Depresi, Kebun, Tanaman Herbal

\section{PENDAHULUAN}

Covid-19 (coronavirus disease 2019) merupakan penyakit pernapasan yang disebabkan oleh virus corona bernama severe acute respiratory syndrome 2 atau biasa disingkat sebagai SARS-CoV-2. Gejala paling umum yang ditimbulkan ialah demam, batuk kering, dan kelelahan. Gejala lain yang kurang umum dan dapat terjadi di beberapa pasien berupa kehilangan indra penciuman, sakit tenggorokan, diare, ruam kulit, dan nyeri otot. Pada penderita tingkat berat, komplikasi dapat menimbulkan kematian termasuk gagal pernafasan, sindrom gangguan pernafasan akut, atau kegagalan multi organ seperti jantung, hati atau ginjal (WHO, 2020). Kelompok usia yang mengalami kematian paling banyak sebagai penderita Covid-19 ialah kelompok lansia berusia 80 tahun atau lebih dengan persentase mencapai $21,9 \%$.
Pada usia pra-lansia (50-59 tahun) angka kematian hampir $2 \%$, usia 60-69 tahun 4 terus naik menjadi 8 sampai $15 \%$ pada usia diatas 70 tahun (Kemenkes, 2021).

Menurut Undang-Undang Republik Indonesia Nomor 36 Tahun 2009 tentang Kesehatan pada Pasal 183 Ayat 1 dalam Dewi (2018) menyatakan bahwa "Upaya pemeliharaan kesehatan bagi lansia harus ditujukan untuk menjaga agar tetap hidup sehat dan produktif secara sosial maupun ekonomis sesuai dengan martabat kemanusiaan”. Seiring berjalannya waktu, lansia mengalami kemunduran fungsi-fungsi tubuh, sehingga menyebabkan lansia rentan terkena gangguan kesehatan. Menurut Kurnianto (2015), penyebab kemunduran fungsi tubuh pada lansia adalah kurangnya pengetahuan tentang manfaat aktivitas fisik yang harus dilakukan serta kurangnya dukungan dari lingkungan sosial. Kegiatan fisik yang dilakukan 
tentunya harus memperhatikan kondisi lansia yang terkait, seperti fungsi paru. Menurut Sukendra (2015), kekebalan tubuh yang ditingkatkan melalui latihan fisik dapat meningkatkan jumlah leukosit (utamanya limfosit dan neutrofil) dalam darah yang berperan sebagai sistem imun tubuh.

Kegiatan bercocok tanam dapat dijadikan sebagai suatu teknik intervensi dan kedekatan terhadap alam yang digunakan sebagai program terapi dan rehabilitasi. Penurunan fisik, mental dan sosial dapat mengarahkan lansia untuk menjadi tidak yakin terhadap kemampuannya sendiri. Akibatnya, lansia menjadi cenderung menolak menjalankan tugas yang diberikan karena merasa kurang mampu. Ariyani (2014) menambahkan bahwa minimnya kegiatan dan aktivitas yang dilakukan oleh pihak Panti werdha menyebabkan para lansia menjadi bermalas-malasan dan tidak ingin melakukan aktivitas apapun. Hortikultura terapi memberikan kesempatan bagi lansia untuk melatih dan menjaga kemampuan motorik. Program hortikultura terapi juga membantu lansia untuk meningkatkan kepercayaan diri serta memunculkan rasa puas ketika tanaman yang mereka tanam dapat tumbuh, lansia akan diajak untuk lebih mampu mengontrol hidupnya serta memberikan tujuan dalam kegiatan sehari-hari.

Luaran yang diharapkan dari kegiatan ini yaitu menjadi media pembelajaran alternatif yang edukatif, aplikatif, dan menyenangkan serta dapat digunakan secara berkelanjutan dalam kurikulum Panti Werdha terbaru. Para lansia mampu mengaplikasikan ilmu praktik bercocok tanam secara langsung dari pelatihan yang akan dilakukan. Para lansia mampu mengaplikasikan ilmu mengenai gizi serta manfaatnya secara langsung dan dapat termotivasi untuk melaksanakan kegiatan secara berkelanjutan dan belajar lebih banyak mengenai bercocok tanam. Tujuan dari kegiatan ini untuk memberdayakan lansia agar tetap sehat dan produktif melalui penanaman tanaman herbal.

\section{METODE DAN PELAKSANAAN}

\section{Metode}

Pengumpulan data dilakukan dengan cara wawancara pre-test dan post-test. Instumen pengukuran diukur menggunakan Depression, Anxiety, and Stress Scale/DASS-21 (Lovibond dan Lovibond, 1995) untuk depresi, kecemasan, dan stres; Spiritual WellBeing Scale/SWBS (Paloutzian dan Ellison, 1983) untuk tingkat kesejahteraan spiritual; dan Physical 
Activity Scale for Elderly/PASE (Washburn dan Montoye, 1986) untuk tingkat aktivitas fisik lansia.

\section{Pelaksanaan Kegiatan}

Kegiatan dilakukan pada bulan Juni hingga September 2021 secara blended (daring : luring $=60: 40$ ) dengan 10 rangkaian kegiatan. Kegiatan luring terdiri dari orientasi dan berkebun 1 sedangkan untuk kegiatan berkebun 2, monitoring, edukasi gizi, senam gembira, dan wawancara post-test dilakukan secara daring. Subjek terdiri dari 16 lansia dengan usia 55 sampai 89 tahun. Kegiatan ini dilaksanakan di Panti Sosial Tresnda Werdha (PSTW) budi mulia 3, Jakarta Selatan. PSTW Budi Mulia 3 merupakan lembaga masyarakat yang secara umum menampung Penyandang Masalah Kesejahteraan Sosial (PMKS). Masalah sosial tersebut dari kelompok lanjut usia yang berada di jalanan dan khususnya lanjut usia yang tidak mampu/kurang beruntung berasal dari masyarakat Jakarta.

\section{HASIL DAN PEMBAHASAN}

Penjelasan mengenai programprogram melansia yang telah diimplentasikan sejak Juni-September 2021 yaitu kegiatan Melansia diikuti oleh 16 peserta yang terdiri dari 13 perempuan dan 3 laki-laki dengan kisaran umur 55-
89 tahun yang juga melibatkan karyawan Panti. Program dijalankan secara hybrid melalui turun langsung ke Panti dan dengan bantuan media sosial yaitu whatsapp, google meeting dan zoom meeting. Kegiatan terdiri dari orientasi, pembuatan video praktik berkebun, pelaksanaan berkebun 1, monitoring berkebun 1, video edukasi gizi, pembuatan booklet, berkebun 2, monitoring berkebun 2, senam gembira, dan diakhiri dengan wawancara pengisian post-test.

Program berkebun yang dilaksanakan pada program ini menggunakan tiga tanaman herbal antara lain bunga rosella, daun mint, dan temulawak. Ketiga tanaman tersebut memiliki kandungan antioksidan yang tinggi sehingga dapat meningkatkan imunitas tubuh seseorang. Hal tersebut sangat penting untuk diperhatikan di masa pandemi bagi kesehatan lansia. Berikut merupakan pelaksanaan program kegiatan berkebun.

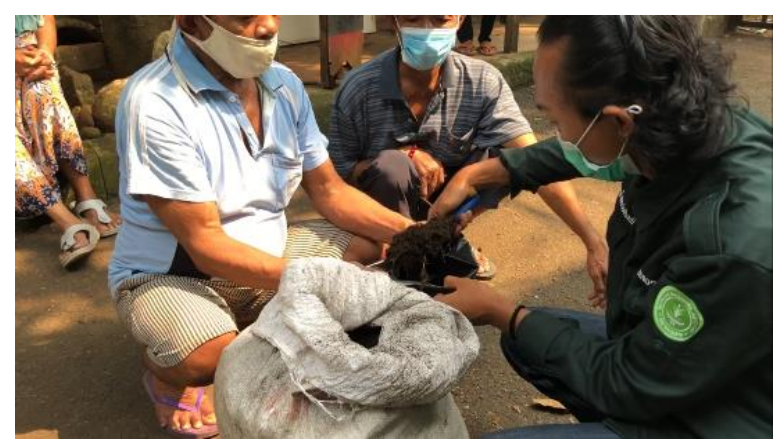

Gambar 1. Program Berkebun Tanaman Herbal 
Untuk meningkatkan pengetahuan tentang manfaat dari tanaman herbal maka dilaksanakan kegiatan edukasi gizi. Kegiatan edukasi gizi dilaksanakan secara daring melalui aplikasi zoom meeting. Edukasi gizi yang diberikan meliputi 1) tips sehat selama pandemi, 2) tips meningkatkan daya tahan tubuh dengan menerapkan 10 pesan gizi seimbang, serta 3) tips atasi stres untuk mencapai jiwa yang sehat. Berikut merupakan pelaksanaan kegiatan edukasi gizi.

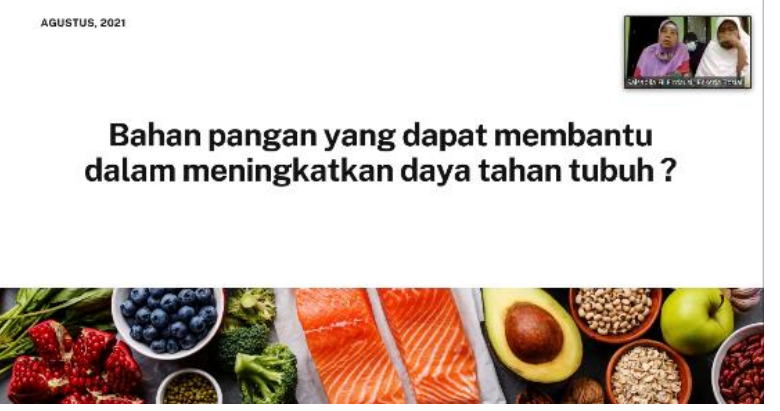

Gambar 2. Program Edukasi Gizi

Demi tercapainya keberhasilan kegiatan melansia secara optimal, aktivitas fisik para lansia merupakan salah satu faktor yang diperhatikan selain tingkat stres para lansia. Hasil penelitian Kurnianto (2015), menyebutkan bahwa kurangnya aktivitas fisik merupakan salah satu penyebab terjadinya kemunduran/kerusakan pada fungsi tubuh lansia. Aktivitas fisik yang dilakukan pada kegiatan ini yaitu senam gembira. Senam gembira dilakukan secara daring dengan bantuan dari perawat/petugas Panti Sosial. Kegiatan senam gembira merupakan salah satu alternatif yang dapat dilakukan untuk meningkatkan aktivitas fisik dan menjaga kebugaran lansia. Berikut merupakan pelaksanaan kegiatan senam gembira.

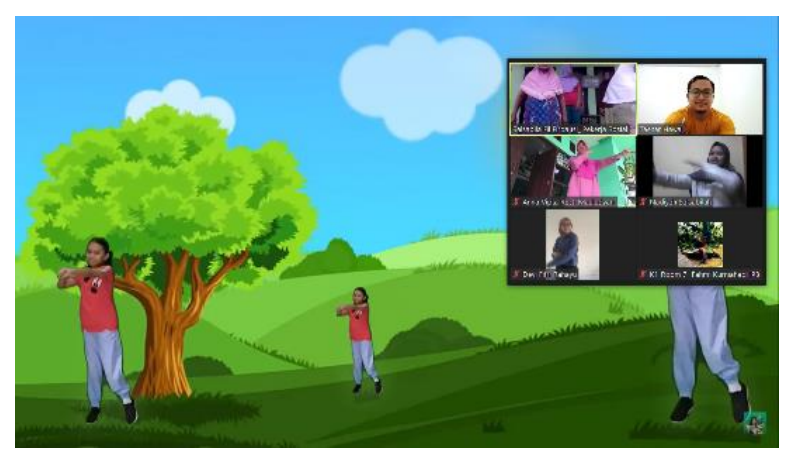

Gambar 3. Program Senam Gembira

\section{Capaian Program}

Capaian program melansia diukur menggunakan instrumen: Depression, Anxiety, and Stress Scale/DASS-21 (Lovibond dan Lovibond, 1995) untuk depresi, kecemasan, dan stres; Spiritual Well-Being Scale/SWBS (Paloutzian dan Ellison, 1983) untuk tingkat kesejahteraan spiritual; dan Physical Activity Scale for Elderly/PASE (Washburn dan Montoye, 1986) untuk tingkat aktivitas fisik lansia. Sebelum terlaksana kegiatan melansia, terdapat 88\% lansia yang memiliki tingkat depresi normal. Angka ini meningkat hingga mencapai 100\% setelah pelaksanaan. Hal yang sama juga terjadi pada komponen kecemasan, dari $88 \%$ menjadi $100 \%$ lansia yang memiliki tingkat kecemasan normal. Seluruh lansia memiliki tingkat 
stres normal baik sebelum dan sesudah kegiatan melansia.

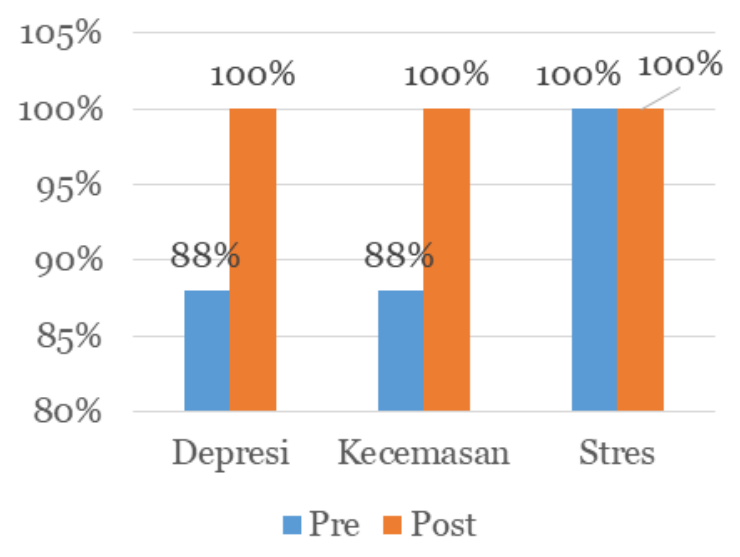

Gambar 4. Grafik Perbandingan Tingkat

Depresi, Kecemasan, dan Stres

Terdapat peningkatan yang signifikan pada proporsi lansia dengan tingkat kesejahteraan spiritual yang tinggi hingga mencapai 88\%. Sebelum dilaksanakan kegiatan melansia hanya terdapat $19 \%$ yang memiliki tingkat kesejahteraan spiritual yang tinggi. Tingkat aktivitas fisik juga mengalami peningkatan dari 75\% menjadi 79\% lansia dengan aktivitas fisik yang baik.

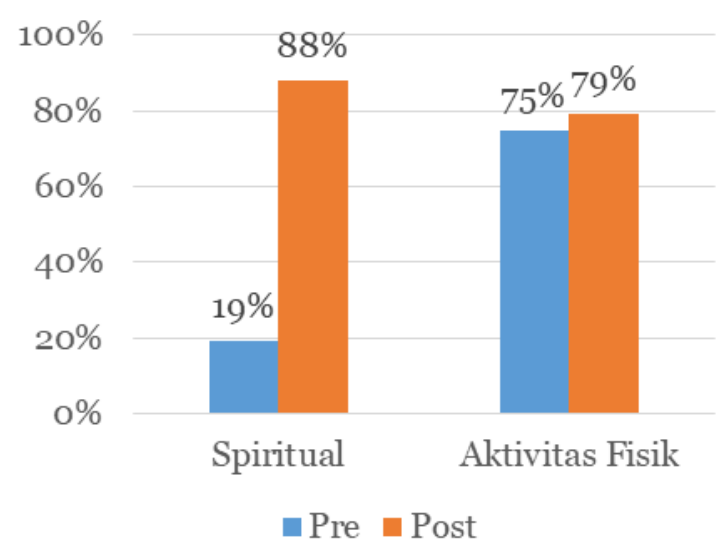

Gambar 5. Grafik Perbandingan Tingkat

Spiritual dan Aktivitas Fisik
Dari t3otal 16 lansia yang diambil datanya pada saat pre-test, terdapat 2 lansia yang tidak dapat melengkapi data post-test. Hal tersebut dikarenakan 2 lansia tersebut mengalami sakit sehingga tidak memungkinkan untuk dilakukan wawancara pengisian post-test. Di akhir program sebanyak 14 lansia mengikuti program melansia hingga selesai.

\section{Hambatan dan Solusi}

Tingginya kasus positif Covid-19 di lokasi mitra serta adanya pemberlakuan PPKM darurat menyebabkan terhambatnya kegiatan luring/turun lapang. Kegiatan yang terhambat diantaranya berkebun 2, senam gembira, dan edukasi gizi. Beberapa tanaman yang ditanam pada kegiatan berkebun 1 tidak tumbuh. Sehingga, solusi yang dilakukan yaitu kegiatan yang awalnya luring dibuat menjadi daring dengan beberapa bantuan aplikasi seperti zoom meeting, whatsapp, dan youtube dengan mengantarkan secara langsung bahan-bahan yang digunakan kepada pengurus Panti Sosial. Solusi tanaman yang tidak tumbuh, tim menggantinya dengan bibit tanaman yang baru.

\section{Potensi Keberlanjutan}

Perawat/petugas Panti Sosial telah diberi pelatihan sebagai pendamping kegiatan melansia sehingga dapat melatih lansia lainnya untuk dapat 
melakukan kegiatan berkebun. Kegiatan ini juga akan menjadi kegiatan baru di lokasi mitra sehingga dapat dilaksanakannya kegiatan rutin para lansia. Pengajuan proposal corporate social responsibility (CSR) kepada Dinas Kelautan, Pertanian, dan Ketahanan Pangan DKI Jakarta untuk dapat menghibahkan tanaman herbal kepada pihak Panti sebagai pendukung dalam keberlanjutan kegiatan berkebun tanaman herbal.

\section{PENUTUP}

\section{Simpulan}

Melansia merupakan solusi dalam melatih lansia anti-stres di masa pandemi melalui kegiatan berkebun tanaman herbal yang terbukti dapat menurunkan tingkat stres pada lansia, serta dapat meningkatkan tingkat kesejahteraan spiritual dan aktivitas fisik lansia. Kegiatan ini memiliki keunikan dibandingkan dengan kegiatan berkebun lainnya yaitu menanam tiga jenis tanaman herbal yang terdiri dari rosella, mint, dan temulawak yang kemudian dapat dikonsumsi dan dimanfaatkan oleh lansia, tersedianya olahan-olahan yang dapat menunjang pemanfaatan hasil dari tanaman herbal, serta didukung dengan kegiatan edukasi dan konsultasi gizi. Lansia juga menjadi terampil dalam melakukan kegiatan berkebun serta lebih peduli terhadap kesehatan

\section{Saran}

Perlu adanya pengembangan kegiatan lebih luas kepada lansia untuk lebih memaksimalkan dalam melatih lansia anti-stres terutama di masa pandemi. Kegiatan ini perlu dilakukan dengan keterlibatan multi sektoral terutama dengan Dinas Kelautan, Pertanian, dan Ketahanan Pangan DKI Jakarta untuk dapat menghibangkan tanaman herbal kepada Panti Sosial sebagai program rutin sebagai pencegah stres para lansia.

\section{Ucapan Terima Kasih}

Ucapan terima kasih kami sampaikan kepada Kementerian Riset, Teknologi, dan Pendidikan Tinggi (Kemendikbudristek) yang telah membiayai program melansia melalui Program Kreativitas Mahasiswa bidang Pengabdian Masyarakat (PKM-PM) tahun 2021 serta para donatur yang turut berpartisipasi dalam menyukseskan program ini sehingga program dapat dilaksanakan dengan baik..

\section{DAFTAR PUSTAKA}

Ariyani, A.M., 2014. Lansia di Panti werdha studi deskriptif mengenai proses adaptasi lansia di Panti werdha hargo dedali surabaya 
[skripsi]. Surabaya: Universitas Airlangga.

Baga, H.Z., Sujana T., Wibowo A.T., 2017. Perspektif lansia terhadap aktivitas fisik dan kesejahteraan jasmani di Desa Margosari Salatiga. Jurnal Ilmu Keperawatan. 8(2): 89-99.

Dewi, S.K., 2018. Level aktivitas fisik dan kualitas hidup warga lanjut usia. Jurnal MKMI. 14(3): 241-250.

KEMENKES., 2021. Hindari Lansia dari COVID-19. Jakarta (ID): Kemenkes RI.

Kurnianto, D., 2015. Menjaga kesehatan di usia lanjut. Jurnal Olahraga Prestasi. 11(2): 19-30.

Lovibond, S.H., Lovibond, P.F., 1995. Manual for The Depression Anxiety \& Stress Scale 2nd Edition. Sydney: Psychology Fondation.

Paloutzian, R.F., Ellison C.W., 1982. Loneliness, Spiritual Well-Being and Quality of Life. New York (US): Wiley.

Sukendra, D.M., 2015. Efek olahraga ringan pada fungsi imunitas terhadap mikroba patogen: infeksi virus dengue. Jurnal Media Ilmu Keolahragaan Indonesia. 5(2): 57 -65 .
Washburn, R.A., Montoye H.J., 1986. Assesment of physical activity by questionnaire: a review. $A m \quad J$ Epidemiol. 123: 563-576.

Wasityastuti, W., Dhamarjati, A., Siswanto., 2019. Imunosenesens dan kerentanan populasi usia lanjut terhadap coronavirus disease 2019 (Covid-19). Jurnal Respirologi Indonesia. 40(3): 182-191. WHO., 2020. Coronavirus disease (COVID-19). Geneva: WHO. 